\title{
Antioksidativna aktivnost i kinetička analiza tokoferolnog ekstrakta iz različitih vrsta biljnih ulja
}

\section{Antioxidant activity and kinetic analysis of tocopherol extract obtained from different types of vegetable oils}

\author{
Paola Tijan ${ }^{1 *}$, Dalibor Broznić ${ }^{2}$
}

${ }^{1}$ Sveučilište u Rijeci, Medicinski fakultet, Rijeka

${ }^{2}$ Sveučilište u Rijeci, Medicinski fakultet, Zavod za medicinsku kemiju, biokemiju i kliničku kemiju, Rijeka

"Dopisni autor:

Paola Tijan, univ. bacc. sanit. ing. Medicinski fakultet Sveučilišta u Rijeci Braće Branchetta 20, 51000 Rijeka e-mail: paolatijan@gmail.com

http://hrcak.srce.hr/medicina
Sažetak. Cilj: Utvrditi razliku u antioksidativnoj aktivnosti maslinovog, suncokretovog, bučinog i crnog ulja i njihovih tokoferolnih ekstrakata te proučiti kinetiku i mehanizam reakcije između slobodnih radikala i antioksidansa. Materijali i metode: Antioksidativna aktivnost ulja i tokoferolnih ekstrakata mjerena je spektrofotometrijski uz uporabu DPPH' (2,2-difenil-1-pikril-hidrazil), dok je Trolox ekvivalent poslužio kao referentni standard za kvantifikaciju rezultata dobivenih DPPH' testom. Pomoću kinetičkih monofaznih i bifaznih matematičkih modela procijenjena je i analizirana inhibicija signala DPPH'. Rezultati: Vrijednost TEAC-a ukazuje da maslinovo i suncokretovo ulje $(2,16 \mathrm{mmol} / \mathrm{L})$ posjeduju jaču antioksidativnu aktivnost $u$ odnosu na crno $(1,85 \mathrm{mmol} / \mathrm{L})$ i bučino ulje $(1,68 \mathrm{mmol} / \mathrm{L})$, a ujedno i intenzivniju inhibiciju DPPH radikala. Tokoferolni ekstrakti imaju puno slabiji antioksidativni učinak od analiziranih biljnih ulja, pri čemu je najdjelotvorniji ekstrakt suncokretova ulja koji čini 22,1\% antioksidativne aktivnosti ulja, a najslabiji ekstrakt bučina ulja sa samo $13,9 \%$. Nestanak DPPH radikala u uzorcima ulja odvija se u dva susljedna koraka, početnog eksponencijalnog koji se odvija unutar 7 min reakcije, ovisno o vrsti ulja, i drugog sporog, gdje su promjene proporcionalne s vremenom. Kod tokoferolnih ekstrakata brzi korak reakcije nije uočen, ukazujući time da se reakcija odvija mehanizmom kinetike prvog reda. Zaključak: Rezultati ukazuju da biljna ulja imaju jači učinak u inhibiciji radikala u odnosu na tokoferolne ekstrakte, pa se njihovom pravilnom konzumacijom potpomaže organizmu u "borbi“ protiv slobodnih radikala. Zapravo, najvažniji dio antioksidacijskog sustava obrane organizma od slobodnih radikala čini sinergističko djelovanje antioksidansa, odnosno antioksidansi u sinergiji imaju jači učinak nego sumarni učinak svih pojedinačnih antioksidansa.

Ključne riječi: antioksidativna aktivnost; biljno ulje; DPPH ; kinetička analiza; TEAC; tokoferoli

Abstract. Aim: To determine the difference in the antioxidant activity of the olive, sunflower, pumpkin and black oil and their tocopherol extracts as well as to examine the kinetics and mechanism of reactions between free radicals and antioxidants. Materials and Methods: Antioxidant activity of the oils and tocopherol extracts was measured spectrophotometrically using DPPH' (2,2-diphenyl-1-picrylhydrazil) while Trolox equivalent was used as a reference standard for the quantification of the results obtained by the DPPH test. DPPH signal inhibition was evaluated and analyzed by monophasic and biphasic kinetics mathematical models. Results: The TEAC values suggest that olive and sunflower oil $(2.16 \mathrm{mmol} / \mathrm{L})$ have a stronger antioxidant activity than black $(1.85 \mathrm{mmol} / \mathrm{L})$ and pumpkin oil $(1.68 \mathrm{mmol} / \mathrm{L})$ and they possess stronger inhibition of the $\mathrm{DPPH}^{\cdot}$ radical. Tocopherol extracts have a much

Napomena: Rad je prezentiran na 10. studentskom kongresu Prehrana i klinička dijetoterapija (10. - 11. svibnja 2019., Rijeka; organizatori: Medicinski fakultet Sveučilišta u Rijeci, FOSS MedRi) te je prema Uredništvu časopisa Medicina Fluminensis odabran za najbolje konferencijsko priopćenje. 
weaker antioxidant effect than the analyzed vegetable oils, where the sunflower extract is most effective, making $22.1 \%$ of the antioxidant oil activity, while the weakest extract is the pumpkin oil extract oil with only $13.9 \%$. DPPH radical disappearance in oil samples takes place in two successive phases, the initial exponential which takes place within $7 \mathrm{~min}$ of the reaction, depending on the oil type, and the second slow phase where the changes are proportional to the time. The rapid reaction phase by tocopherol extracts was not noticed, indicating that the reaction takes places by the mechanism of the first order kinetics. Conclusion: The results indicate that vegetable oils have a stronger effect on the radical inhibition than the tocopherol extracts, and by their proper consumption they will support the organism in the "fight" against free radicals. In addition, the most important role of the antioxidant defense system against free radicals makes the synergic interactions among the different molecules present in the food, indicating that antioxidants in synergy have a stronger potential than the sum of all individual antioxidants.

Key words: antioxidant activity; DPPH; kinetic analysis; TEAC; tocopherols; vegetable oils

\section{UVOD}

Posljednjih godina sve se više istražuju uzroci i posljedice oksidativnog stresa, kao i njegova uloga u etiologiji i progresiji brojnih humanih bolesti ${ }^{1}$. U živom organizmu tijekom metaboličkih procesa nastaju reaktivni kisikovi spojevi, koji u velikom broju mogu uništiti strukturu biomolekula ili modificirati njihovu funkciju, dovodeći tako do disfunkcije i smrti stanice. U prevenciji bolesti i promociji zdravlja veliku važnost ima hrana bogata potrebnim nutrijentima². Njihovo pozitivno djelovanje očituje se u smanjenju štetnih učinaka slobodnih radikala u ljudskom organizmu, djelovanjem antioksidansa i smanjenjem broja oksidacijskih reakcija. Danas se vrlo često upotrebljava pojam „superhrana“ koji podrazumijeva hranu bogatu biološki aktivnim tvarima koje mogu djelovati kao inhibitori određenih enzima, kao „gasioci“ singletnog kisika, sudjelovati u reakcijama hvatanja slobodnih radikala ili razgradnji peroksida ${ }^{3}$. Dokazano je da povećana konzumacija ovakve hrane, koja je bogat izvor antioksidansa, prevenira različite humane bolesti, uključujući karcinom, kardiovaskularne i neurodegenerativne bolestit, ${ }^{4}$. Upravo su se biljna ulja, čija uporaba sve više raste širom svijeta, poglavito $u$ mediteranskom području, pokazala kao takva namirnica, tim više jer se dobivaju od plodova usjeva koji su vrlo rasprostranjeni u svijetu, stoga i vrlo lako dostupna ${ }^{6,7}$. U ljudskoj prehrani dominantnu ulogu ima suncokretovo ulje, a u današnje vrijeme sve se više koriste maslinovo i bučino ulje. Suncokretovo ulje odlikuje se stabilnošću pri višim temperaturama pa se preporučuje za prženje, dok pretjerano zagrijavanje maslinova ulja može uništiti njegove nutrijente, stoga ga je najbolje koristiti u salatama ili dodati na gotova jela. Bučino ulje ima vrlo dugu tradiciju proizvodnje i konzumacije, pogotovo u sjevernom dijelu Republike Hrvatske. Najčešće se koristi kao dodatak salatama, ali ga u

Biljna ulja imaju jači učinak u odnosu na tokoferolne ekstrakte, pa se njihovom konzumacijom potpomaže organizmu u borbi protiv slobodnih radikala. Najvažniji dio antioksidacijskog sustava obrane organizma od slobodnih radikala čini sinergijsko djelovanje antioksidansa, odnosno, antioksidansi u sinergiji imaju jači učinak nego sumarni učinak svih pojedinačnih antioksidansa.

zemljama Dalekog Istoka i nekim državama Afrike koriste za kuhanje ${ }^{8}$. Općenito, biljna ulja su visokovrijedne namirnice bogate biološki važnim nutrijentima kao što su bjelančevine, esencijalne masne kiseline, minerali (željezo, magnezij), vitamini (B, C, D, E i K) koji sprječavaju nastanak raznih bolesti-13. $U$ biološki aktivne komponente biljnih ulja ubraja se i vitamin E koji čini skupina tokoferola i tokotrienola, koji se zajedničkim imenom nazivaju tokoli. To su lipofilne komponente, derivati kroman-6-ola s 1 do 3 metilne skupine na aromatskom prstenu i nezasićenim (tokotrienoli) ili zasićenim (tokoferoli) izoprenoidnim lancem od 16 ugljikovih atoma na 2. položaju. Postoji 8 izomernih oblika, četiri tokoferola ( $\alpha$-, $\beta$-, $\gamma$ - i $\delta$ - tokoferol) i četiri tokotrienola ( $\alpha-, \beta-, \gamma$ - i $\delta$ - tokotrienol), koji se skupnim imenom nazivaju tokokromanoli. $U$ biljnim uljima dominantniji su tokoferoli, među kojima prevladavaju $\alpha$-, $\gamma^{-}$i $\delta$ - tokoferoli, dok je $\beta$-tokoferol prisutan u vrlo malom udjelu. Naime, zahvaljujući hidroksilnoj skupini na kromanolnom prstenu koja može otpustiti vodikov atom i njime reducirati slobodni radikal, tokoferoli se ubrajaju u značajne antioksidanse. Polinezasićene masne kiseline staničnih membrana izrazito su osjetljive na oštećenja slobodnim radikalima, s obzirom na to da sadrže penta-1,4-diene kojima se lako uklanja 
atom vodika u reakciji sa slobodnim radikalom. Pri toj reakciji nastaje lipoperoksil slobodni radikal, koji može napasti susjednu polinezasićenu masnu kiselinu i tako započeti lančanu reakciju s vrlo štetnim posljedicama za membransku strukturu. Uloga tokoferola je zaustaviti lančanu reakciju odnosno lipidnu peroksidaciju i spriječiti daljnja oštećenja, donirajući vodikov atom radikalu masne kiseline $^{14-17}$. Proučavanje ovako složene reakcije moguće je utvrđivanjem kinetičkih parametara reakcije što će imati za posljedicu potpuniji uvid u antioksidativno ponašanje pojedinih spojeva. Općenito, kinetika reakcije, koja ovisi o specifičnim čimbenicima, služi kao najvažniji pokazatelj za pretpostavku mogućeg reakcijskog mehanizma, odnosno niz koraka prilikom kojih se reaktanti pretvaraju u produkte kemijske reakcije. Bolje razumijevanje mehanizama proučavanih reakcija moguće je postići analitičkim procjenama koje uključuju kinetičke, odnosno matematičke modele ${ }^{18-20}$.

Ovo istraživanje bilo je usmjereno na praćenje sposobnosti hvatanja slobodnih radikala od strane antioksidansa maslinova, suncokretova, bučina, crnog ulja, te njihovih tokoferolnih ekstrakata, a radi ispitivanja utjecaja sinergije antioksidansa na antioksidativnu aktivnost. Nadalje, proučavana je i uključenost pojedinih vrsta antioksidansa na mehanizam reakcije između slobodnih radikala i antioksidansa prisutnih u biljnim uljima i tokoferolnim ekstraktima.

\section{MATERIJALI I METODE}

\section{Kemikalije i reagensi}

Za pripremu uzoraka ulja i tokoferolnog ekstrakta korištene su kemikalije laboratorijske čistoće: kalij-hidroksid (Kemika, Zagreb, Hrvatska), etanol
(Carlo Erba Reagens, Val-de-Reuil, Francuska), etilacetat (99,8 \%; Fluka Chemicals, St. Gallen, Švicarska), L(+)-askorbinska kiselina (Merck, Darmstadt, Njemačka) te kemikalije HPLC čistoće: propan-2-ol, metanol, heksan (J. T. Baker, Deventer, Nizozemska). Testovi antioksidativne aktivnosti provedeni su pomoću reagensa: 2,2-difenil-1-pikrilhidrazil (DPPH' radikal; $\mathrm{C}_{18} \mathrm{H}_{12} \mathrm{~N}_{5} \mathrm{O}_{6}$ ) i 6-hidroksi-2,5,7,8-tetrametilkroman-2-karboksilne kiseline (Trolox, $\mathrm{C}_{14} \mathrm{H}_{18} \mathrm{O}_{4}$ ) proizvođača Sigma-Aldrich Chemie, Merck (Taufkirchen, Njemačka).

\section{Priprema uzoraka biljnih ulja za test antioksidativne aktivnosti}

Analizirane su četiri vrste biljnih ulja kupljene u maloprodaji: suncokretovo ulje (uzorak SU) proizvođača „Zvijezda d. o. o.“ (Zagreb, Hrvatska), maslinovo ulje (uzorak MU) proizvođača „Monini S. p. A.“ (Spoleto, Italija), nerafinirano bučino ulje (uzorak BU) iz uljare „Poljo Posavec d. o. o.“ (Nedelišće, Hrvatska) te domaće crno ulje (uzorak CU) (mješavina nerafiniranog bučinog ulja i rafiniranog suncokretova ulja) proizvođača „Plodine d. o. o." (Rijeka, Hrvatska). U tablici 1 prikazane su hranjive vrijednosti navedenih ulja, njihova energetska vrijednost, udio masti, ugljikohidrata i bjelančevina u $100 \mathrm{~mL}$ ulja.

\section{Priprema tokoferolnog ekstrakta iz analiziranih biljnih ulja}

Tokoferoli su iz uzoraka ulja ekstrahirani sukladno metodi koju je predložio $\mathrm{Xu}^{21} \mathrm{~s}$ manjim prilagodbama. Prije ekstrakcije tokoferola ulja su podvrgnuta alkalnoj hidrolizi s kalijevim hidroksidom tako da se u odvagu ulja od 0,100 g ( \pm 0,001 g) dodaje $0,05 \mathrm{~g}$ askorbinske kiseline te smjese alkohola $(90,2 \%$ etanola, 4,9 \% metanola i 4,9\% pro-

Tablica 1. Energetska vrijednost, udio masti, ugljikohidrata i bjelančevina na $100 \mathrm{~mL}$ analiziranih biljnih ulja

\begin{tabular}{|l|c|c|c|c|}
\cline { 2 - 4 } \multicolumn{1}{c|}{} & \multicolumn{4}{c|}{ Uzorci ulja } \\
\hline Prosječna hranjiva vrijednost na $\mathbf{1 0 0} \mathrm{mL}$ & SU & MU & BU & CU \\
\hline Energetska vrijednost (kcal/kJ) & $828 / 3404$ & $828 / 3404$ & $827 / 3401$ & $100 / 19$ \\
\hline Masti/ zasićene masne kiseline (g/g) & $92 / 11$ & $92 / 14$ & $92 / 16$ & 0 \\
\hline Ugljikohidrati (g) & 0 & 0 & 0 & 0,14 \\
\hline Bjelančevine (g) & 0 & 0 & 0 & 0 \\
\hline
\end{tabular}

SU - suncokretovo ulje; MU - maslinovo ulje; BU - bučino ulje; CU - crno ulje 
pan-2-ola) te $80 \%$ otopine kalijevog hidroksida. Nakon inkubiranja 30 min u vodenoj kupelji zagrijanoj na $70{ }^{\circ} \mathrm{C}$ uzorci su ekstrahirani s n-heksanom i centrifugirani (Jouan BR4i multifunction centrifuge, Thermo Electron Corporation, SaintHerblain, France) 15 min na $1000 \times g$ kako bi se odijelio heksanski sloj, nakon čega je heksanski sloj uparen u struji dušika.

\section{Određivanje antioksidativne aktivnosti biljnih ulja i tokoferolnog ekstrakta DPPH testom}

Sposobnost uzoraka ulja i tokoferolnih ekstrakata u inhibiranju radikala određena je DPPH' testom, odnosno nestanku DPPH' radikala zbog reakcije s antioksidansima prisutnima u ulju odnosno ekstraktu sukladno metodi koju su opisali Kalantzakis i sur. ${ }^{22}$ Uzorci ulja za test antioksidativne aktivnosti pripremljeni su vaganjem odgovarajuće mase ulja odnosno ekstrakta otapanjem u etilacetatu kako bi se postigla ishodna koncentracija od 0,05 g/mL. $1 \mathrm{~mL}$ svake otopine uzorka pomiješan je s $3 \mathrm{~mL} \mathrm{0,1} \mathrm{mmol/L} \mathrm{etilacetatne} \mathrm{otopine}$ $\mathrm{DPPH}^{`}$ radikala. Smanjenje intenziteta $\mathrm{DPPH}{ }^{`}$ radikala određeno je mjerenjem apsorbancije smjese na 515 nm, koristeći spektrofotometar Cary 100 Bio WinUV (Agilent Technologies, Santa Clara, CA, USA) uz etilacetat kao slijepu probu. Apsorbancija je mjerena svake min (za kinetičku analizu) tijekom 60 min kada je reakcija dosegla stabilno stanje. Ukupna antioksidativna aktivnost ulja i ekstrakata izračunata je kao postotak inhibicije DPPH` prema jednadžbi (1):

$\mathrm{DPPH}^{*}$ inhibicija $=\frac{A_{\text {kontrola }}-A_{\text {uzorka }}}{A_{\text {uzorka }}} \cdot 100$

U jednadžbi $1, A_{\text {kontrola }}$ i $A_{\text {uzorak }}$ predstavljaju apsorbancije etilacetatne otopine $\mathrm{DPPH}^{\circ}$ bez uzorka kao negativnu kontrolu pri $\mathrm{t}=0 \mathrm{~min}$ i apsorbanciju uzorka pri $\mathrm{t}=60 \mathrm{~min}$. Antioksidativni kapacitet izražen je TEAC testom pomoću Trolox ekvivalenta (engl. Trolox equivalent antioxidat capacity) koji je analog vitamina E. Opseg inhibicije DPPH uspoređen je sa standardnom krivuljom Troloxa u rasponu $0-0,21 \mathrm{mmol} / \mathrm{L}$. Kvantitativna analiza sposobnosti hvatanja radikala izražena je u mmolima Trolox ekvivalenta (TE) po kilogramu ulja odnosno ekstrakta prema jednadžbi (2):

$\left(\frac{n(\mathrm{TE})}{m(\text { ulja/ekstrakta })}\right)=\frac{c(\mathrm{TE}) \cdot v_{\text {otopine }} \times 100}{m(\text { ulja/ekstrakta })}$
U jednadžbi 2, c(TE) predstavlja koncentraciju Troloxa iz standardne krivulje koja je ekvivalentna DPPH inhibiciji otopine ulja/ekstrakta, $V$ je ukupni volumen $(\mathrm{mL})$ otopine ulja/ekstrakta $(10 \mathrm{~mL})$, a $m$ masa (g) uzoraka ulja/ekstrakta.

\section{Kinetička analiza inhibicije signala DPPH radikala}

Inhibicija signala DPPH` radikala procijenjena je i analizirana pomoću kinetičkih matematičkih modela prikazanih jednadžbama:

Model kinetike prvog reda (KPR):

$$
A_{t}=A_{0} \times \mathrm{e}^{-k_{1} t}
$$

Dvostruki eksponencijalni model prvog reda (DEPR):

$$
A_{t}=A_{1} \times \mathrm{e}^{-k_{1} t}+A_{2} \times \mathrm{e}^{-k_{2} t}+A_{r}
$$

U jednadžbama $3,4 A_{0^{\prime}} A_{\mathrm{t}^{\prime}} A_{1}, A_{2}$ i $A_{\mathrm{r}}$ su omjeri apsorbancije na početku reakcije, u vremenu $t$, u fazama 1 i 2 u vremenu $\mathrm{t}=0$ i rezidualni omjer, $k_{1} \mathrm{i}$ $k_{2}$ su konstante brzine kemijske reakcije, $t$ je vrijeme reakcije. Krivulje dobivene s pretpostavljenim matematičkim modelima prikazane su nelinearnim regresijskim modelima, dostupnim u komercijalnom programskom paketu Wolfram Research Mathematica ${ }^{\circ}$ v. $9.0^{23}$.

\section{Statistička obrada podataka}

Deskriptivna statistička analiza, kao i svi ostali statistički izračuni, provedeni su pomoću komercijalnog softvera Statistica ${ }^{\bullet}$ v. $13.0^{24}$ na razini značajnosti $p<0,05$. Testovi antioksidativne aktivnosti provedeni su na uzorcima od kojih su pripremljena četiri poduzorka, a svaki je poduzorak analiziran u duplikatu. Rezultati su izraženi kao medijan. Normalnost razdiobe podataka testiran je Kolmogorov-Smirnovljevim testom. Raspodjela se ne može opisati kao normalna, zbog čega su korišteni neparametrijski testovi. Statistička analiza antioksidativne aktivnosti analizirana je Kruskal-Wallisovim ANOVA testom, a razlike između pojedinih uzoraka ulja i ekstrakata pomoću Mann-Whitneyjeva U-testa. Slaganje rezultata predloženog matematičkog modela s eksperimentalnim podacima procijenjeno je pomoću koeficijenta determinacije $\left(R^{2}\right.$, jednadžba 5), koeficijenta varijacije srednjeg kvadratnog odstupanja (SRMSE; jednadžba 6 i pogreške hi-kvadrat testa ( $\chi 2$ pogreška; jednadžba 7$)$ : 
$R^{2}=\left\{\frac{\sum_{i=1}^{N}\left(A_{\text {exp }, i}-\bar{A}_{\text {exp }, i}\right)\left(A_{\text {mod, },}-\bar{A}_{\text {mod }, i}\right)}{\sqrt{\sum_{i=1}^{N}\left(A_{\text {exp }, i}-\bar{A}_{\text {exp }, i}\right)^{2} \sum_{i=1}^{N}\left(A_{\text {mod, }, i}-\bar{A}_{\text {mod, }, i}\right)^{2}}}\right\}^{2}$

SRMSE $=\frac{1}{\overline{A_{\text {exp }, \mathrm{i}}}} \sqrt{\frac{\sum_{i=1}^{N}\left(A_{\text {exp }, \mathrm{i}}-A_{\text {mod }, \mathrm{i}}\right)^{2}}{N}}$

$\chi^{2}$ pogreška $=100 \times \sqrt{\frac{2}{\chi^{2} \text { tablično }} \sum_{i=1}^{N} \frac{\left(A_{\text {exp }, i}-A_{\text {modi }, i}\right)^{2}}{\bar{A}_{\text {exp }, i}{ }^{2}}}$

U jednadžbama 5, 6 i 7, $A_{\text {exp }} A_{\text {mod }}$ su eksperimentalne i vrijednosti dobivene modelom, $\overline{A_{\text {exp }, 1}} \mathrm{i} \overline{A_{\text {mod, }, 1}}$ su srednje vrijednosti eksperimentalnih odnosno vrijednosti dobivenih modelom, $N$ je broj mjerenja. Ovisnost konstanti brzine kemijske reakcije i sposobnosti hvatanja radikala (TEAC) testiran je neparamatrijskim testom (Kendall-Tau) i višestrukom regresijskom analizom.

\section{REZULTATI}

\section{Antioksidacijska aktivnost analiziranih biljnih ulja i njihovih tokoferolnih ekstrakata}

Za procjenu antioksidacijske aktivnosti analiziranih uzoraka biljnih ulja i njihovih tokoferolnih ekstrakata te za objašnjenje mehanizama u kontroli kinetike reakcije korišten je test inhibicije DPPH radikala. Kinetika nestanka DPPH' radikala u uzorcima prikazana je na slici 1 , gdje je prikazana ovisnost gubitka DPPH signala u odnosu na vremenski tijek reakcije. Kao što je vidljivo na slici
1, nestanak DPPH`radikala u uzorcima ulja odvija se u dva susljedna koraka; početnog, gdje je uočljiv brzi eksponencijalni nestanak DPPH', nakon čega slijede spore promjene proporcionalne $s$ vremenom.

Vrijeme brzog koraka reakcije određena je Diskontinuiranim bifaznim modelom prvog reda (Model nije prikazan u radu) i grafički potvrđeno nagibom krivulje nestanka DPPH' u početnom koraku $^{25}$. Najdulje vrijeme brzog koraka reakcije postignuto je u uzorku ulja SU (6,86 min; tablica 2), a najkraće u uzorku MU (3,11 min). Na kraju brzog koraka reakcije, uzorci ulja MU i SU inhibirali su 49,85 odnosno $53,83 \%$ početne količine DPPH', dok je postotak inhibicije za uzorke BU i CU bio manji i iznosio 30,37 odnosno 37,51 \%. Također, na kraju reakcije ukupna količina inhibiranog $\mathrm{DPPH}^{\prime}$ bila je značajno niža u uzorcima BU $\mathrm{i}$ CU (53,53 odnosno 59,56 \%) u odnosu na uzorke SU i MU (69,51 odnosno 71,03 \%). lako je vrijeme prvog koraka reakcije nestanka DPPH' u uzorcima BU i CU identično (5,01 min) mogu se ipak uočiti male razlike $u$ inhibiciji u brzom koraku kao i na kraju reakcije (tablica 2). Suprotno tome, kod uzorka MU postignuto je kraće vrijeme brzog koraka u odnosu na SU (3,11 odnosno 6,86 $\mathrm{min}$ ) uz istovremenu jaču inhibiciju DPPH` što ukazuje da SU sporije reagira S DPPH, no na kraju reakcije postiže skoro istu antioksidativnu aktivnost kao $\mathrm{i}$ MU. Kod tokoferolnih ekstrakata postignuto je

Tablica 2. Antioksidativna aktivnost (RSA) uzoraka biljnih ulja i njihovih tokoferolnih ekstrakata u prvom (brzom) koraku reakcije i na kraju reakcije

\begin{tabular}{|c|c|c|c|}
\hline Uzorak ulja / tokoferolni ekstrakt & $\boldsymbol{t}_{\mathbf{1}} / \mathbf{m i n}$ & $\mathbf{R S A}^{\mathrm{a}} / \%$ & $\mathbf{R S A}^{\mathrm{b}} / \%$ \\
\hline SU & 6,86 & 49,85 & 69,51 \\
\hline MU & 3,11 & 53,83 & 71,03 \\
\hline BU & 5,01 & 30,37 & 53,53 \\
\hline CU & 5,01 & 37,51 & 59,56 \\
\hline SUe & 1,14 & 5,47 & 28,30 \\
\hline MUe & 0,33 & 7,70 & 18,60 \\
\hline BUe & 1,34 & 0,01 & 10,92 \\
\hline CUe & 0,75 & 0,05 & 20,80 \\
\hline
\end{tabular}

Vrijednosti su izražene kao medijan. $t_{1}$ - vrijeme brzog koraka reakcije inhibicije DPPH' radikala; ${ }^{\text {a }}$ - postotak DPPH radikala uhvaćen u brzom koraku reakcije; ${ }^{b}$ - postotak DPPH radikala uhvaćen na kraju reakcije. SUe - tokoferolni ekstrakt suncokretova ulja; MUe - tokoferolni ekstrakt maslinova ulja; BUe - tokoferolni ekstrakt bučina ulja; CUe - tokoferolni ekstrakt crnog ulja; Za skraćenice uzoraka ulja pogledati tablicu 1. 
puno kraće vrijeme brzog koraka reakcije (tablica 2) u odnosu na analizirana ulja, ukazujući praktički na nepostojanje brzog koraka reakcije te drugačiji mehanizam reakcije između $\mathrm{DPPH}^{\cdot}$ i tokoferolnih ekstrakata. Također, inhibicija DPPH bila je puno niža, kako u brzom tako i u sporom koraku reakcije u odnosu na analizirana ulja.

Kvantitativna analiza antioksidativne aktivnosti uzoraka ulja i tokoferolnih ekstrakata izražena kao koncentracija TEAC-a u mmol/kg ulja ili tokoferolnog ekstrakta za pojedini uzorak prikazana je na slici 2. Uzorci SU i MU posjeduju jednake TEAC vrijednosti $(2,16 \mathrm{mmol} / \mathrm{kg})$, dok su vrijednosti za CU i BU znatno niže i iznose 1,85 odnosno 1,68 $\mathrm{mmol} / \mathrm{kg}$. Razlike TEAC vrijednosti pojedinih vrsta ulja analizirane su statistički te je utvrđeno da postoji statistički značajna razlika između antioksidativne aktivnosti SU i BU ( $p=0,0233)$, između BU i MU ( $p=0,0081)$ i između MU i CU ( $p=$ $0,0154)$. Nisu pronađene statistički značajne razlike $\mathrm{u}$ antioksidativnoj aktivnosti između SU i MU, SU i CU te BU i CU (slika 2). Vrijednosti TEAC uzoraka tokoferolnih ekstrakata bile su znatno niže u odnosu na uzorke ulja i nalazile su se u rasponu od 0,23 (BUe) do 0,48 mmol/kg (SUe). Usporedbom TEAC vrijednosti nisu pronađene statistički značajne razlike $u$ antioksidativnoj aktivnosti između pojedinih uzoraka tokoferolnih ekstrakata. Nadalje, testirane su i razlike TEAC vrijednosti između antioksidativne aktivnosti uzoraka ulja i njihovih tokoferolnih ekstrakata te je utvrđena statistički značajna razlika na razini značajnosti $p<0,05$ (slika 2).

\section{Kinetička analiza inhibicije signala DPPH radikala $u$ analiziranim uzorcima biljnih ulja $\mathbf{i}$ njihovim tokoferolnim ekstraktima}

Da bi se objasnio mehanizam koji kontrolira brzinu reakcije inhibicije DPPH u uzorcima ulja i njihovih tokoferolnih ekstrakata eksperimentalni podaci testirani su KPR (jednadžba 3) i DEPR (jednadžba 4) kinetičkim matematičkim modelima, kako je objašnjeno u poglavlju Materijali i metode. Nakon razmatranja statističkih pokazatelja $\left(R^{2}\right.$, SRMSE i $\chi^{2}$ pogreška) i prikladnosti slaganja rezultata dobivenih matematičkim modelima $\mathrm{s}$ eksperimentalnim rezultatima, može se zaključiti da bifazni kinetički model bolje opisuje reakciju inhibicije DPPH' od monofaznog modela u uzorci-

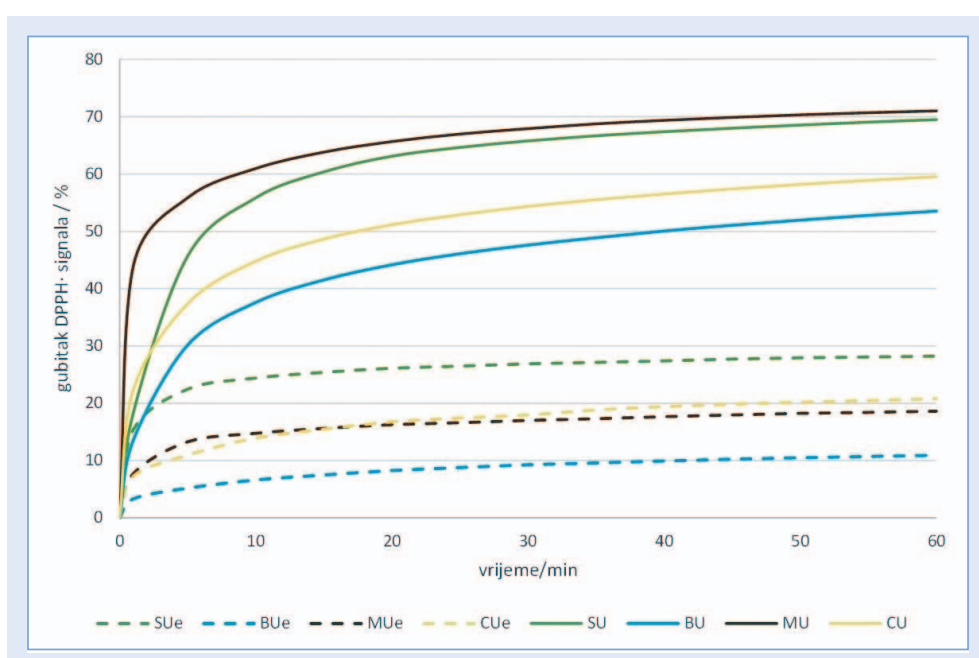

Slika 1. Gubitak signala DPPH' radikala u reakciji sa suncokretovim (SU), bučinim (BU), maslinovim (MU) i crnim uljem (CU) te tokoferolnim ekstraktima suncokretova (SUe), bučina (BUe), maslinova (MUe) i crnog ulja (CUe). Rezultati su prikazani kao medijan.

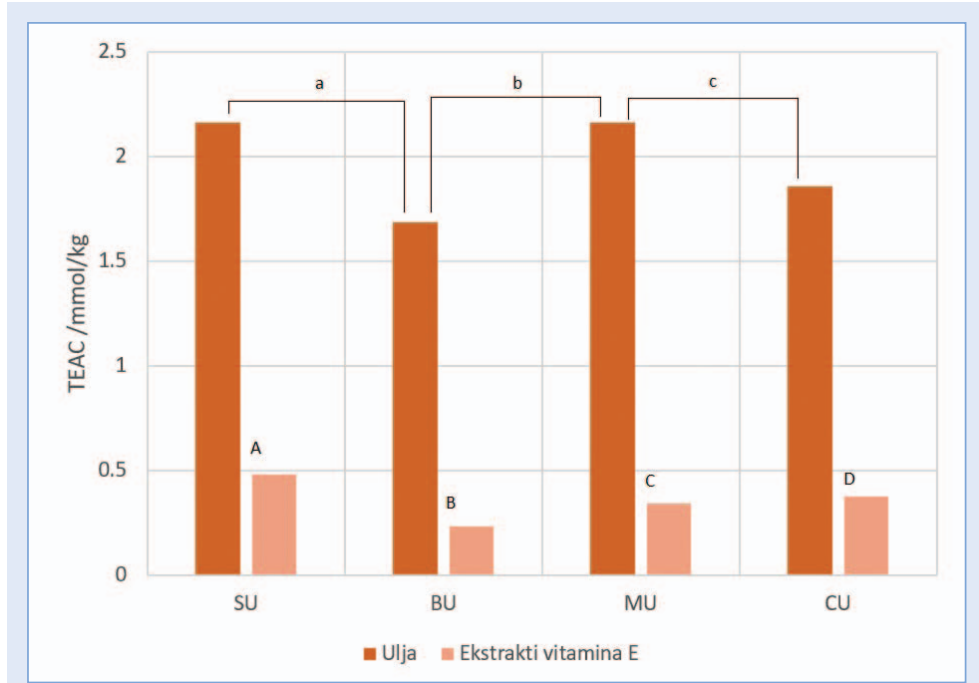

Slika 2. Antioksidativna aktivnost (DPPH' test) za suncokretovo (SU), bučino (BU), maslinovo (MU) i crno ulje (CU) te tokoferolnog ekstrakta suncokretova (SUe), bučina (BUe), maslinova (MUe) i crnog ulja (CUe). Statistički značajne razlike $(p<0,05)$ između: a- SU i BU, b- BU i MU, c- MU i CU, A- SU i SUe, B- BU i BUe, C- MU i MUe i D- CU i CUe.

ma ulja, što potvrđuju visoki koeficijent determinacije i niske vrijednosti $\chi^{2}$ pogreške tablica 3 ). Bifazno ponašanje inhibicije DPPH' za uzorak SU koji je odabran kao reprezentativni uzorak svih vrsta ulja prikazano je na slici 3a, gdje su eksperimentalni podaci preostalog DPPH' prikazani zajedno s krivuljama simuliranim s primijenjenim matematičkim modelima. Također je prikazan i tzv. „rezidualni“ prikaz (umetnut na sliku 3a) na 
Tablica 3. Primijenjeni kinetički matematički modeli, procijenjeni kinetički parametri i statistički pokazatelji pri određivanju antioksidativne aktivnosti suncokretova (SU), maslinova (MU), bučina (BU) i crnog ulja (CU)

\begin{tabular}{|c|c|c|c|c|}
\hline \multirow{2}{*}{ Model/parametar } & \multicolumn{4}{|c|}{ Uzorci ulja } \\
\hline & SU & MU & BU & CU \\
\hline \multicolumn{5}{|c|}{ Model kinetike prvoga reda } \\
\hline$k_{1}(1 / \min )$ & 0,0158 & 0,0119 & 0,0930 & 0,0104 \\
\hline $\mathrm{R}^{2}$ & 0,9633 & 0,9598 & 0,9916 & 0,9868 \\
\hline SRMSE & 0,1997 & 0,2066 & 0,0919 & 0,1164 \\
\hline$\chi^{2}$ pogreška (\%) & 17,65 & 18,27 & 8,14 & 10,30 \\
\hline \multicolumn{5}{|c|}{ Bifazni model kinetike prvoga reda } \\
\hline$A_{1}(\%)$ & 42,96 & 49,93 & 26,37 & 30,45 \\
\hline$A_{2}(\%)$ & 25,82 & 21,73 & 27,90 & 28,40 \\
\hline$k_{1}(1 / \mathrm{min})$ & 0,4366 & 1,9382 & 0,0425 & 0,8799 \\
\hline$k_{2}(1 / \min )$ & 0,0687 & 0,0744 & 0,4441 & 0,0609 \\
\hline $\mathrm{R}^{2}$ & 0,9999 & 0,9998 & 0,9999 & 0,9998 \\
\hline SRMSE & 0,0086 & 0,0112 & 0,0063 & 0,0128 \\
\hline$\chi^{2}$ pogreška (\%) & 0,78 & 1,02 & 0,57 & 1,16 \\
\hline
\end{tabular}

$k_{1} \mathrm{i} k_{2}$ - konstante brzine kemijske reakcije; $\mathrm{R}^{2}$ - koeficijent determinacije; SRMSE - koeficijent varijacije srednjeg kvadratnog odstupanja; $\chi^{2}$ pogreška - pogreška hi-kvadrat testa. $A_{1}$ - udio DPPH' u prvom koraku reakcije; $A_{2}$ - udio DPPH' u drugom koraku reakcije.
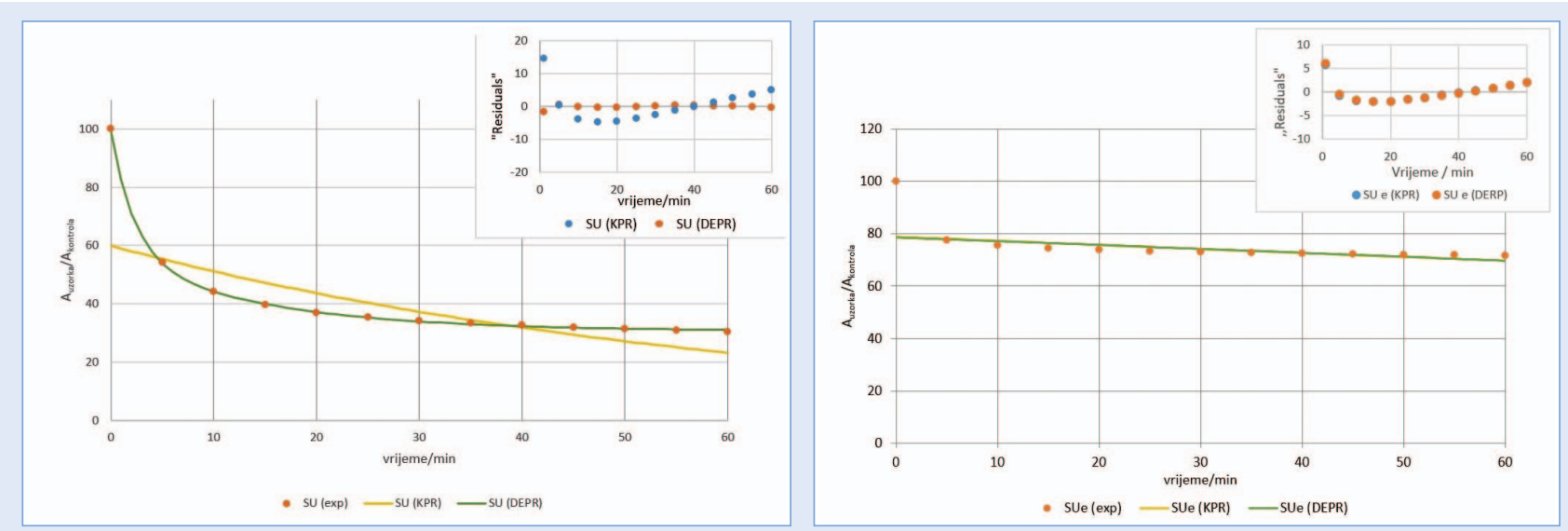

Slika 3. Eksperimentalni podaci i teoretske krivulje dobivene testiranjem matematičkih modela kod reakcije inhibicije DPPH u uzorcima: a) suncokretova ulja (SU) i b) tokoferolnog ekstrakta suncokretova ulja (SUe). (Oznake na slici: exp - eksperimentalne vrijednosti, KPR - vrijednosti dobivene testiranjem Modelom kinetike prvog reda, DEPR - vrijednosti dobivene testiranjem Dvostrukim eksponencijalnim modelom kinetike prvog reda. Rezultati su prikazani kao medijan. Umetnute slike predstavljaju „rezidualni“ dijagram slaganja eksperimentalnih podataka s vrijednostima dobivenih matematičkim modelom.)

kojem je uočljivo da su rezultati primijenjenog DEPR modela bliži nuli od KPR modela, što dodatno ukazuje na bifaznost reakcije inhibicije. Suprotno prethodno navedenom, kod uzoraka tokoferolnih ekstrakata uočeno je da jednostavniji KPR model jednako dobro opisuje ponašanje nestanka DPPH kao i složeniji DEPR model (tablica 4, slika 3b). Sukladno svim dobivenim rezultatima, može se zaključiti da je primjena bifaznog DEPR modela prihvatljivija za opisivanje reakcije inhibicije DPPH ${ }^{\circ}$ u uzorcima ulja, dok je kod tokoferolnih ekstrakata opravdano primijeniti jednostavniji KPR model.

\section{RASPRAVA}

Budući da su biljna ulja složene smjese mnogih fitokemikalija, vrlo teško je odrediti koja je od njih odgovorna za antioksidativno djelovanje. Osim toga, potrebno je poznavati udjele pojedinih antioksidativnih komponenti prisutnih u uljima, kao i 
Tablica 4. Primijenjeni matematički modeli, procijenjeni kinetički parametri i statistički pokazatelji pri određivanju antioksidativne aktivnosti tokoferolnih ekstrakata suncokretova (SUe), maslinova (MUe), bučina (BUe) i crnog ulja (CUe)

\begin{tabular}{|c|c|c|c|c|}
\hline \multirow{2}{*}{ Model/parametar } & \multicolumn{4}{|c|}{ Uzorci tokoferolnog ekstrakta ulja } \\
\hline & SUe & MUe & BUe & CUe \\
\hline \multicolumn{5}{|l|}{ Model kinetike prvoga reda } \\
\hline$k_{1}(1 / \min )$ & 0,0020 & 0,0015 & 0,0012 & 0,0023 \\
\hline $\mathrm{R}^{2}$ & 0,9982 & 0,9994 & 0,9998 & 0,9994 \\
\hline SRMSE & 0,0417 & 0,0227 & 0,0100 & 0,0226 \\
\hline$\chi^{2}$ pogreška (\%) & 3,69 & 2,01 & 0,89 & 1,99 \\
\hline \multicolumn{5}{|c|}{ Bifazni model kinetike prvoga reda } \\
\hline$A_{1}(\%)$ & 44,94 & 27,36 & 25,48 & 35,58 \\
\hline$A_{2}(\%)$ & 44,94 & 27,36 & 25,48 & 35,58 \\
\hline$k_{1}(1 / \mathrm{min})$ & 0,0015 & 0,0020 & 0,0020 & 0,0025 \\
\hline$k_{2}(1 / \min )$ & 0,0015 & 0,0021 & 0,0020 & 0,0024 \\
\hline $\mathrm{R}^{2}$ & 0,9981 & 0,9994 & 0,9998 & 0,9994 \\
\hline SRMSE & 0,0422 & 0,0232 & 0,0105 & 0,0238 \\
\hline$\chi^{2}$ pogreška (\%) & 3,83 & 2,10 & 0,95 & 2,16 \\
\hline
\end{tabular}

njihov sinergistički ili antagonistički utjecaj, stoga je provedeno ovo istraživanje o antioksidativnoj aktivnosti tokoferolnih ekstrakata izoliranih iz raznih vrsta biljnih ulja. Usporedba rezultata antioksidativne aktivnosti biljnih ulja u našoj studiji s drugim studijama vrlo je teško izvediva, jer svaki lokalitet na kojem raste biljka suncokreta, masline ili buče karakteriziran je različitim geološkim, hidrološkim i klimatskim obilježjima. Posljedica toga je različit kemijski sastav biljnih ulja te posljedično, različita i antioksidativna aktivnost. Rezultati antiradikalne aktivnosti uzoraka biljnih ulja, u našem istraživanju izraženi kao Trolox ekvivalent, bili su u rasponu od 1,68 do $2,16 \mathrm{mmol} / \mathrm{kg}$ ulja, s dominantnim djelovanjem uzoraka SU i MU. Vrlo slične rezultate dobili su Castelo-Branco i sur. ${ }^{26}$ od $2,44 \mathrm{mmol} / \mathrm{kg}$ suncokretova ulja s područja Brazila, Pellegrini i sur. od $1,79 \mathrm{mmol} / \mathrm{kg}$ maslinova ulja s područja Italije ${ }^{27}$, Nawirska-Olszanska i sur. i Prescha i sur $1,34 \mathrm{mmol} / \mathrm{kg}$ odnosno $1,44 \mathrm{mmol} / \mathrm{kg}$ ovisno o sorti buče ${ }^{28,29}$. Međutim, u literaturi su pronađene i niže vrijednosti antioksidativne aktivnosti nego $u$ ovoj studiji, maslinovo ulje s područja Austrije $(0,97-1,25$ $\mathrm{mmol} / \mathrm{kg})^{30}$ i Hrvatske $(0,55-1,30 \mathrm{mmol} / \mathrm{kg}$, ovisno o sorti masline $)^{31-32}$ suncokretovo ulje s područja Austrije $(0,12 \mathrm{mmol} / \mathrm{kg})^{30}$, s područja
„Brzi“ i „spori“ antioksidansi prisutni u biljnim uljima u reakciji s radikalima uzrokuju bifaznost ponašanja nestanka radikala. Kod tokoferolnih ekstrakata inhibiciju radikala uzrokuju samo „spori“ antioksidansi. To ukazuje da se reakcija inhibicije radikala u biljnim uljima i ekstraktima odvija različitim reakcijskim mehanizmima.

Italije $1,17(\mathrm{mmol} / \mathrm{kg})^{27}$. Isto tako, Zoumpoulakis i sur. pronašli su daleko više vrijednosti od 3,10 do $13,3 \mathrm{mmol} / \mathrm{kg}$ za suncokretovo ulje s područja $\mathrm{Grčke}^{33}$. Dobiveni rezultati radikalske inhibicije u ovoj studiji ukazuju da tokoferolni ekstrakti imaju puno slabiji antioksidativni učinak od analiziranih biljnih ulja. Najdjelotvorniji je SUe koji čini 22,1 \% antioksidativne aktivnosti ulja, a najslabiji BUe samo $13,9 \%$. Uz pretpostavku da su tokoferoli odgovorni za uklanjanje oko $40 \%$ radikala ${ }^{30} \mathrm{i}$ uzimajući u obzir maseni udio tokoferola, kao i njihov doprinos uklanjanju radikala $\left(A_{1}\right.$ i $\left.A_{2}\right)$, može se zaključiti da posjeduju različitu učinkovitost kao antioksidansi. Svakako ne treba zanemariti ni činjenicu da je najvažniji dio antioksidacijskog sustava obrane organizma od slobodnih radikala zapravo sinergističko djelovanje antioksidansa. Naime, dokazano je da djelovanje antioksidansa 
u sinergiji ima jači učinak nego zbroj pojedinačnih učinaka antioksidansa ${ }^{34}$. Također, neki autori zagovaraju koantioksidativnu aktivnost tokoferola i drugih antioksidansa prisutnih u hrani, kao što su askorbati ili flavonoidi, te da dolazi do djelomične regeneracije između tokoferola (osobito $\delta$-izomera) i flavonoida ${ }^{35}$.

Dobiveni rezultati o kinetici inhibicije $\mathrm{DPPH}^{`}$ radikala ukazuju na bifaznost reakcije nestanka radikala odnosno da se reakcija između radikala i antioksidansa u uljima odvija s dva različita mehanizma reakcije. Stoga je kinetički model DEPR odabran za detaljnije objašnjenje mehanizma reakcije. Općenito, reakcija između DPPH radikala i antioksidansa prisutnih u uljima započinje prijenosom najslabije vezanog $\mathrm{H}$-atoma s molekule antioksidansa na slobodni radikal. Novonastali slabije reaktivni radikal $\left(A^{*}\right)$ može reagirati s drugom molekulom DPPH' radikala ili reakcijom disproporcioniranja stvoriti stabilnije produkte. Dobiveni rezultati ovom studijom o bifaznosti procesa nestanka radikala u skladu su s nekoliko prethodnih studija. Espin i sur. ${ }^{19}$ koji su proučavali antioksidativnu aktivnost 57 jestivih biljnih ulja različitih vrsta i iz većeg broja europskih država (Francuske, Grčke, Italije, Španjolske i Turske) pretpostavili su da razlog bifaznog ponašanja može biti povezan sa složenošću reakcija koje se odvijaju između radikala i antioksidansa, budući da uključuju dvije različite skupine antioksidansa te se reakcije odvijaju različitim kemijskim putevima.

To znači da antioksidansi prisutni u ulju imaju različite sposobnosti u inhibiciji radikala, budući da reagiraju različitim brzinama te time uzrokuju dva koraka reakcije. Ukupna brzina reakcije određena je dvjema konstantama, $k_{1}$ i $k_{2}$, koji predstavljaju brzinu nestanka DPPH' (jednadžba 4). Kod uzoraka ulja SU, MU i CU konstante brzine $k_{1}$ puno su veće u odnosu na konstante $k_{2}$, što ukazuje da je kod ovih vrsta ulja ukupna brzina reakcije određena sporijim procesom odnosno drugim korakom reakcije. Kod uzorka ulja BU uočen je obrnut proces, odnosno da je ukupna brzina reakcije limitirana prvim korakom koji je sporiji proces $u$ odnosu na drugi korak reakcije. Udio inhibiranog DPPH u brzom koraku reakcije $\left(A_{1}\right)$ kod uzoraka SU i MU bio je znatno veći od udjela u sporom koraku reakcije $\left(A_{1}\right)$, dok su kod uzoraka BU i CU udjeli u oba koraka reakcije bili približno jednaki (tablica 3). To potvrđuje prethodnu činjenicu o postojanju dvaju vrsta antioksidansa, „brzih“ i „sporih", te različit mehanizam reakcije i kod uzoraka SU i MU u odnosu na BU i CU. Pod pretpostavkom da tijekom reakcije svi antioksidansi i „brzi“ i „spori“ prisutni u ulju reagiraju s DPPH“ radikalom, konstante brzine reakcije mogu predstavljati brzinu nestanka antioksidansa. Nadalje, kako bi se ispitao mogući utjecaj konstanti brzine reakcije na sposobnost inhibiranja radikala, korišten je statistički neparametrijski test Kendall-Tau. Korelacijska analiza između TEAC vrijednosti i konstanti brzine dobivenih iz DEPR modela ukazuje da na prvu fazu nestanka DPPH` u uzorcima ulja pozitivno utječe $k_{1}(0,46)$, dok je odnos između TEAC i $k_{2}$ negativan $(-0,15)$, ali njihov utjecaj nije bio statistički značajan na razini $p<0,05$. Uz neparametrijski test korištena je i višestruka linearna regresijska analiza koja istovremeno uspoređuje antioksidativnu aktivnost (TEAC) i konstante brzine $\left(k_{1}\right.$ i $\left.k_{2}\right)$, uz pretpostavku linearnog prediktivnog modela za TEAC vrijednosti. Ova analiza rezultirala je sljedećim korelacijama za TEAC:

$$
\begin{aligned}
& \text { TEAC }=0,0606 \times k_{1}-0,8113 \times k_{2}+2,0485 \\
& \left(R^{2}=0,6044\right) .
\end{aligned}
$$

Jednadžba ukazuje da antioksidansi uključeni u drugi korak reakcije imaju ključni učinak na nestanak $\mathrm{DPPH}^{\cdot} \mathrm{u}$ eksperimentalnim uzorcima ulja. Slično bifazno ponašanje nestanka DPPH' pronađeno je u istraživanju koje su proveli Broznić i sur. o antioksidativnoj aktivnosti bučinih ulja s područja Međimurja, Podravine i Slavonije ${ }^{18}$. Autori takvo ponašanje pripisuju prisutnosti antioksidativnih spojeva u matriksu koji imaju funkcionalne skupine sposobne za brzo i sporo doniranje vodikova atoma. Prema tome, spojevi koji pokazuju brzu i sporu antiradikalnu kinetiku imaju različite sposobnosti inhibiranja radikala te reagiraju različitom brzinom s radikalima u bifaznoj reakciji. Kod tokoferolnih ekstrakata ne može se govoriti o bifaznosti procesa zbog toga što su udjeli inhibiranog radikala u obje faze jednaki kao i njihove konstante (tablica 4), odnosno, mehanizam se odvija prema kinetici prvog reda s istom konstantom brzine kemijske reakcije tijekom cijelog procesa. Dakle, u tokoferolnom ekstraktu postoji vrlo 
mali broj brzih antioksidansa koji mogu donirati slabo vezani $\mathrm{H}$-atom s molekule antioksidansa na slobodni radikal.

\section{ZAKLJUČCI}

Rezultati dobiveni studijom ukazuju da konzumacijom biljnih ulja potpomažemo organizmu u „borbi“ protiv slobodnih radikala te da biljna ulja imaju jači učinak u inhibiranju radikala u odnosu na ekstrakte tokoferola. Može se zaključiti da je zapravo najvažniji dio antioksidacijskog sustava obrane organizma od slobodnih radikala sinergističko djelovanje antioksidansa, odnosno da antioksidansi u sinergiji imaju jači učinak nego sumarni učinak svih pojedinačnih antioksidansa. $U$ analiziranim uljima utvrđen je bifazni mehanizam inhibicije radikala, stoga je predložen Dvostruki eksponencijalni model prvog reda za opis reakcije antioksidansa i radikala, ukazujući da antioksidansi mogu reagirati različitim brzinama s radikalima te time uzrokovati dva koraka reakcije. Za detaljnije proučavanje kinetike i mehanizma reakcije inhibicije DPPH $^{\circ}$ radikala potrebno je napraviti detaljnu kvantifikaciju tokoferolnog ekstrakta kao i ostalih skupina antioksidansa prisutnih u uljima te proučiti njihovo sinergističko/antagonističko djelovanje u odnosu na ishodna ulja, što će biti uključeno u naša buduća istraživanja.

\section{Zahvala}

Istraživanje je provedeno u okviru znanstveno-istraživačkog projekta broj 6.7.1.1.1.80 uz potporu Sveučilišta u Rijeci.

Izjava o sukobu interesa: Autori izjavljuju da ne postoji sukob interesa.

\section{LITERATURA}

1. La Vecchia C, Altieri A, Tavani A. Vegetables, fruit, antioxidants and cancer: a review of Italian studies. Eur J Nutr 2001;40:261-7.

2. Terry P, Terry JB, Wolk A. Fruit and vegetable consumption in the prevention of cancer an update. J Intern Med 2001;250: 280-90.

3. Cohen JH, Kristal AR, Stanford JL. Fruit and vegetable intakes and prostate cancer risk. J Natl Cancer Inst 2000;92:61-8.

4. Tian $\mathrm{H}$, Zhang $\mathrm{H}$, Zhan $\mathrm{P}$, Tian F. Composition and antioxidantnt and antimicrobal activities of white apricot almond (Amygdalus communis L.) oil. Eur J Lipid Sci Tech 2011;113:1138-44.
5. Tian H, Zhan P, Zhang H. Development of fatty acid fingerprint of white apricot almond oil by gas chromatographymass spectrometry. Eur J Lipid Sci Tech 2014;116:126-33.

6. Bagchi D, Bagchi M, Stohs SJ, Das DK, Ray SD, Kuszynski $C D$ et al. Free radicals and grape seeds proanthocyanidin extract: importance in human health and disease prevention. Toxicology 2000;148:187-97.

7. Rufino MSM, Alves RR, Fernandes FAN, Brito ES. Free radical scavening behavior of ten exotic tropical fruit extracts. Food Res Int 2011;44:2072-5.

8. Gohari Ardabili A, Farhoosh R, Haddad Khodaparast $\mathrm{MH}$.Chemical composition and physicochemical properties of pumpkin seeds (Cuc urbita pepo subsp. pepo var. styriaka) grown in Iran. J Agric Sci and Tehnol 2010;13: 1053-63.

9. Salgado PR, Drago SR, Molina Ortiz SE, Petruccelli S, Andrich O, González RJ et al.Production and characterization of sunflower (Helianthus annuus L.) protein-enriched products obtained atpilot plant scale. Food Sci Technol 2012;45:65-72.

10. Amakura Y, Yoshimura M, Yamakami S, Yoshida T. Isolation of phenolic constituents and characterization of antioxidant markers from sunflower (Helianthus annuus) seed extract. Phytochem Lett 2013;6:302-5.

11. Rigacci S, Guidotti V, Bucciantina M, Parri M, Nediani C, Cerebai $\mathrm{E}$ et al. Oleuropein aglycon prevents cytotoxic amyloid aggregation of human amylin. J Nutr Biochem 2010;21:726-735.

12. Turner R, Etiene N, Garcia-Alonso M, De Pascual-Teresa $S$, Minihane AM et al. Antioxidant and anti-atherogenic activities of olive oil phenolics. Int J Vitam Nutr Res 2005;75:61-70.

13. Bogani P, Galli C, Villa M, Visioli F. Postprandial antiinflammatory and antioxidant effects of extra virgin olive oil. Atherosclerosis 2007;190:181-86.

14. Lúcio $M$, Nunes $C$, Gaspar D, Ferreira H, Lima JLFC, Reis S. Antioxidant Activity of Vitamin E and Trolox: Understanding of the Factors that Govern Lipid Peroxidation Studies In Vitro. Food Biophys 2009;4:312-20.

15. Yoshida $Y$, Saito $Y$, Jones LS, Shigeri Y., Chemical reactivities and physical effects in comparison between tocopherols and tocotrienols: physiological significance and prospects as antioxidants. J Biosci Bioeng 2007;104:439-45.

16. Falk J, Munné-Bosch S. Tocochromanol functions in plants: antioxidation and beyon. J Exp Bot 2010;61:154966.

17. Marquardt D, Williams JA, Kučerka N, Atkinson J, Wassall SR, Katsaras J et al. Tocopherol activity correlates with its location in a membrane: a new perspective on the antioxidant vitamin E. J Am Chem Soc 2013;135:752333.

18. Broznić $D$, Čanadi Jurešić $G$, Milin Č. Involvement of $\alpha$-, $\gamma$ - and $\delta$-Tocopherol Isomers from Pumpkin (Cucurbita pepo L.) Seed Oil or Oil Mixtures in the Biphasic DPPH Disappearance Kinetics. Food Technol. Biotechnology 2016;54:200-10.

19. Espín JC, Soler-Rivas C,Wichers HJ. Characterization of the Total Free Radical Scavenger Capacity of Vegetable Oils and Oil Fractions Using 2,2-Diphenyl-1-picrylhydrazyl Radical. J Agri Food Chem 2000;48:648-56.

20. Terpinc $P$, Bezjak $M$, Abramovič $H$. A kinetic model for evaluation of the antioxidant activity of several rosemary extracts. Food Chem 2009;115:740-744. 
21. Xu Z. Analysis of tocopherols and tocotrienols. Curr Protoc Food Anal Chemi. 2002;D:D1-5.

22. Kalantzakis G, Blekas G, Pegklidou K, Boskou D. Stability and radical-scavenging activity of heated olive oil and othervegetable oils. Eur J Lipid Sci Tech 2006;108:329-35.

23. Wolfram Research Mathematica ${ }^{\circledR}$ [internet], v. 8.0, Champaign, IL, USA: WolframResear ch Co. 2009. [cited 2019 Jul 15]. Available from: http://www.wolfram.com/ mathematica/.

24. STATISTICA [internet], v. 8, StatSoft, Inc, Tulsa, OK, USA; 2007. [cited 2019 Jul 15]. Available from: http://www. statsoft.com

25. Broznić D, Ratkaj I, Malenica Staver M, Kraljević Pavelić $S$, Žurga P, Bubal D et al. Evaluation of the Antioxidant Capacity, Antimicrobial and Antiproliferative Potential of Fir (Abies alba Mill.) Honeydew Honey Collected from Gorski kotar (Croatia). Food Technol Biotech 2018;56: 533-45.

26. Castelo-Branco VN, Santana I, Di-Sarli VO, Pereira Freitas $\mathrm{S}$, Guedes Torres A. Antioxidant capacity is a surrogate measure of the quality and stability of vegetable oils. Euro J Lipid Sci Technol 2015;118:224-35.

27. Pellegrini N, Serafini $M$, Colombi B, Del Rio D, Salvatore $\mathrm{S}$, Bianchi $\mathrm{M}$ et al. Total antioxidant capacity of plant foods, beverages and oils consumed in Italy assessed by three different in vitro assays. J Nutr 2003;133:2812-9.

28. Nawirska-Olszańska A, Kita A, Biesiada A, SokółŁętowska A, Kucharska AZ. Characteristics of antioxidant activity and composition of pumpkin seed oils in 12 cultivars. Food Chem 2013;139:155-61.
29. Prescha A, Grajzer M, Dedyk M, Grajeta H. The Antioxidant Activity and Oxidative Stability of Cold-Pressed Oils. J Am Oil Chem Soc 2014;91:1291-301.

30. Fruhwirth GO, Wenzl T, El-Toukhy R, Siegfried Wagner F, Hermetter A. Fluorescence screening of antioxidant capacity in pumpkin seed oils and other natural oils. Euro $\mathrm{J}$ Lipid Sci Technol 2003;105:266-74.

31. Šarolić $M$, Gugić $M$, Tuberoso $\mathrm{Cl}$, Jerković I, Suste $\mathrm{M}, \mathrm{Ma}$ rijanović $Z$ et al. Volatile profile, phytochemicals and antioxidant activity of virgin olive oils from Croatian autochthonous varieties Mašnjača and Krvavica in comparison with Italian variety Leccino. Molecules 2014;19:881-95

32. Šarolić $M$, Gugić $M$, Friganovic $E$, Tuberoso $C I G$, Jerković I. Phytochemicals and Other Characteristics of Croatian Monovarietal Extra Virgin Olive Oils from Oblica, Lastovka and Levantinka Varieties. Molecules 2015;20:4395409.

33. Zoumboulakis P, Sinanoglu VJ, Siapi E, Heropoulos G, Proestos C. Evaluating Modern Techniques for the Extraction and Characterisation of Sunflower (Helianthus annus L.) Seeds Phenolics. Antioxidants (Basel) 2017;24:6:46.

34. Mishra K, Ojha H, Chaudhury NK. Estimation of antiradical properties of antioxidants using DPPH assay: A critical review and results. Food chem 2012;130:1036-43.

35. Kadoma Y, Ishihara M, Okada N, Fujisawa S. Free radical interaction between vitamin E (alpha-, beta-, gammaand delta-tocopherol), ascorbate and flavonoids. In vivo 2006;20:823-7. 